\title{
Immunotherapies for Immune-Mediated Myopathies: A Current Perspective
}

\author{
Merrilee Needham $^{1,2,3}$ • Frank L. Mastaglia ${ }^{1,3}$
}

Published online: 19 November 2015

(C) The American Society for Experimental NeuroTherapeutics, Inc. 2015

Summary Until recently, the treatment of immune-mediated inflammatory myopathies has largely been empirical with glucocorticoids, steroid-sparing immunosuppressive drugs, and intravenous immunoglobulin. However, a proportion of patients are only partially responsive to these therapies, and there has been a need to consider alternative treatment approaches. In particular, patients with inclusion body myositis are resistant to conventional immunotherapies or show only a transient response, and remain a major challenge. With increasing recognition of the different subtypes of immune-mediated inflammatory myopathies, and improved understanding of their pathogenesis, more targeted treatments are now being trialled. The overall approach to treatment, and novel therapies targeting B cells, T cells, and specific cytokines are discussed in this review.

Keywords Immune-mediated myopathy $\cdot$ Inflammatory myopathy $\cdot$ Myositis $\cdot$ Treatment

Merrilee Needham

Merrilee.Needham@health.wa.gov.au

1 Institute for Immunology and Infectious Diseases, Murdoch University, Murdoch 6150, WA, Australia

2 Fiona Stanley Hospital, Murdoch 6150, WA, Australia

3 West Australian Neuroscience Research Institute, Queen Elizabeth II Medical Centre, Nedlands 6009, WA, Australia

\section{Introduction}

The immune-mediated inflammatory myopathies (IMIM) are classified into the following groups based on their clinicopathological characteristics and underlying immunopathogenetic mechanisms: dermatomyositis (DM), polymyositis (PM), overlap syndrome (OS), inclusion body myositis (IBM), and necrotizing autoimmune myopathies (NAM) [1-4]. The occurrence of immune cell-mediated myocytotoxicity, circulating autoantibodies, and overexpression of major histocompatibility complex (MHC) molecules in muscle tissue supports an autoimmune pathogenesis for these disorders. In the case of IBM there is still debate as to whether the disease is primarily autoimmune in origin or a degenerative myopathy with associated inflammatory features and an immune component [5].

Although the immunopathogenesis of the different forms of IMIM is now reasonably well understood $[2,6]$, the approach to treatment remains largely empirical and still relies primarily on the use of traditional forms of immunotherapy such as corticosteroids and immunosuppressive agents, which, together with intravenous immunoglobulin therapy (IVIG), are the mainstays of treatment for most cases of DM, PM, OS, and NAM. However, recent advances, including B-cell depletion and cytokine-based therapies, have provided important new options for the treatment of more resistant cases. In contrast, most cases of IBM are unresponsive to these forms of immunotherapy and there are as yet no effective disease-modifying therapies for this progressive and disabling disease.

In this review we discuss current approaches to the use of immunotherapeutic agents in the different types of IMIM, as well as emerging new therapies targeting B and T cells, and cytokines. Childhood myositis is outside of the scope of this review. 


\section{Clinical and Diagnostic Aspects}

The clinical diagnosis of IMIM is based on the pattern of muscle weakness and tempo of the disease, and the characteristic skin changes in DM and other systemic features of connective tissue disease in patients with OS, which is one of the largest subgroups (Table 1) [7, 8]. The pattern of muscle involvement is also important in order to exclude other conditions such as "inflammatory" forms of muscular dystrophy (e.g., dysferlinopathy and facioscapulohumeral dystrophy), which can mimic IMIM. In PM, DM, OS, and NAM the time course is usually subacute and there is typically a proximal pattern of limb muscle weakness, which may be more severe in the upper limbs in DM. In more florid cases the weakness is often more generalized and rapidly progressive, and there may also be weakness of the bulbar and respiratory muscles. A more restricted brachioscapulospinal pattern of weakness can occur in patients with OS associated with scleroderma or other autoimmune diseases $[9,10]$. In contrast to the other forms of IMIM, in IBM the clinical course is slowly progressive and there is a more selective pattern of muscle weakness and atrophy, with particular involvement of the quadriceps femoris and forearm finger flexor and extensor muscles, which is often asymmetric and more severe on the nondominant side. Dysphagia due to involvement of the pharyngeal muscles is also common, particularly in cases of IBM.

The muscle biopsy is the definitive diagnostic procedure that allows confirmation of the immune-inflammatory nature of the myopathy, as well as the particular type of IMIM in many cases. Muscle magnetic resonance imaging can be helpful diagnostically in demonstrating the distribution of muscle pathology in the limb and axial muscles, and in some cases may be helpful in selecting the most appropriate muscle to biopsy [7]. The serum creatine kinase (CK) level is usually elevated to varying degrees, particularly in cases of NAM and severe DM or PM. However, it is nonspecific and may be only slightly raised or normal in some cases of DM and IBM.

There is increasing awareness of the importance of myositis autoantibodies as biomarkers for certain subgroups of IMIM, particularly in OS and NAM (Table 1) [8, 11]. Screening for autoantibodies may also be helpful diagnostically in patients in whom the initial clinical manifestations are nonspecific and the muscle biopsy findings are not conclusive [12]. Antihistidyl tRNA synthetase (anti-Jo-1), which is the most common of the antisynthetase antibodies, occurs in about $20 \%$ of cases of PM and DM, and is associated with the antisynthetase syndrome. In IBM, antibodies to cytoplasmic 5'-nucleotidase (anti-cN1A) have been reported in up to

Table 1 Clinical, serological, and pathological features of immune-mediated inflammatory myopathies

\begin{tabular}{|c|c|c|c|c|}
\hline & $\mathrm{DM}$ & $\mathrm{PM} / \mathrm{OS}$ & NAM & IBM \\
\hline Muscle weakness & $\begin{array}{l}\text { Proximal predominant } \\
\quad(\mathrm{UL}>\mathrm{LL})\end{array}$ & $\begin{array}{l}\text { Proximal predominant } \\
\text { or restricted }\end{array}$ & $\begin{array}{l}\text { Proximal predominant } \\
\text { or diffuse }\end{array}$ & $\begin{array}{l}\text { Quadriceps, finger } \\
\text { flexors most affected }\end{array}$ \\
\hline Skin involvement & + & $-($ Can occur in OS $)$ & - & - \\
\hline Association with CTD & + & ++ & + & + \\
\hline Association with malignancy & + & + & + & - \\
\hline $\begin{array}{l}\text { Association with viral infections } \\
\text { (HIV, HTLV-1, hepatitis C) }\end{array}$ & + & + & + & + \\
\hline $\begin{array}{l}\text { Autoantibodies } \\
\text { (antigenic targets) }\end{array}$ & $\begin{array}{l}\text { Mi-2 } \\
\text { MDA5 } \\
\text { TIF-1 } \\
\text { NXP-2 }\end{array}$ & $\begin{array}{l}\text { U1-snRNP } \\
\text { PM-Scl } \\
\text { tRNA synthetases } \\
\text { Nucleoporin (Nup) }\end{array}$ & $\begin{array}{l}\text { SRP } \\
\text { HMGCR }\end{array}$ & $\begin{array}{l}\text { 5'-nucleotidase } \\
\text { (cN1A) }\end{array}$ \\
\hline \multicolumn{5}{|l|}{ Histopathology } \\
\hline Myofiber necrosis & $\begin{array}{l}\text { Fiber groups, perifascicular, } \\
\text { microinfarcts }\end{array}$ & Single fibers & Single fibers & Single fibers \\
\hline Perifascicular atrophy & + & - & - & - \\
\hline Inflammatory infiltrates & $\begin{array}{l}\text { CD4+ cells, B cells, } \\
\text { pDCs }(\text { BDCA2 }+)\end{array}$ & $\begin{array}{l}\text { CD8+ cells, plasma cells } \\
(\mathrm{CD} 138+), \text { mDCs }(\mathrm{BDCA} 1+)\end{array}$ & $\begin{array}{l}\text { Macrophages } \\
(\mathrm{CD} 68+)\end{array}$ & $\begin{array}{l}\text { CD8+ T cells } \\
\text { CD4+ T cells } \\
\text { Plasma cells } \\
\text { pDCs }\end{array}$ \\
\hline MAC (C5b-9) & ++ & - & $+/-$ & - \\
\hline MHC-I/II & ++ & ++ & $+/-$ & ++ \\
\hline Capillary depletion & ++ & $+/-$ & - & - \\
\hline
\end{tabular}

$D M$ dermatomyositis, $P M / O S$ polymyositis/overlap syndrome, $N A M$ necrotizing autoimmune myopathy, IBM inclusion body myositis, $C T D$ connective tissue disease, $H T L V-1$ human T-cell leukemia virus, $M A C$ membrane attack complex, $M H C$ major histocompatibility complex, $U L$ upper limb, $L L$ lower limb, MDA5 melanoma differentiatio-associated gene 5, TIF-1 transcription intermediary factor 1, NXP-2 nuclear matrix protein 2, snRNP small nuclear ribonucleoprotein, $P M-S c 1$ polymyositis-scleroderma, $S R P$ signal recognition particle, $H M G C R$ 3-hydroxy-3-methyl-glutaryl-CoA, $p D C$ plasmacytoid dendritic cells, $m D C$ myeloid dendritic cells 
$70 \%$ of cases $[13,14]$, and, when present, support the diagnosis of IBM in patients with a compatible clinical phenotype. However, as they can also occur in other autoimmune diseases, such as Sjögren's syndrome and systemic lupus erythematosus, their diagnostic utility is reduced in patients with these comorbidities [14, 15].

\section{Immunopathogenesis of Inflammatory Myopathies}

Immunophenotyping has characterized the inflammatory cell populations and immune effector cells in the different types of IMIM. In PM and IBM there is an endomysial inflammatory infiltrate with a predominance of CD8+ T cells surrounding and invading MHC-I expressing myofibers [16]. These cells putatively induce cytotoxic myonecrosis through an interaction between antigen-presenting MHC-I molecules and co-stimulatory molecules on CD8+ cells $[6,17,18]$. The infiltrating cells in PM also include CD68+ macrophages and myeloid dendritic cells, which are thought to participate in the cytotoxic process $[2,19]$, as well as apoptosis-resistant CD8+CD28-/-, CD4+ CD28-/-, cells which have been suggested may contribute to treatment resistance [20]. T-cell receptor profiling has shown that the CD8+ T cells are clonally restricted in situ and persist over time [21-23]. Recent observations suggest that invasion of non-necrotic myofibers by endomysial inflammatory cells is usually indicative of IBM, even in the absence of rimmed vacuoles and other histological changes [24].

In DM a humorally driven process is thought to cause complement-mediated injury to capillary endothelial cells in muscle and skin, resulting in capillary loss, ischemic myofiber necrosis, and atrophy of perifascicular muscle fibers [2]. However, the putative autoantigens and their targets have yet to be identified. The inflammatory infiltrate is predominantly perivascular and perimysial in distribution, and comprises primarily CD4+ T cells, as well as macrophages, B cells and plasma cells, and type 1 interferon (IFN)- $\alpha$ secreting plasmacytoid dendritic cells [25]. Antibodies to a number of ubiquitous autoantigens are present in some cases and serve as markers for subgroups of patients (Table 1), but their role in disease pathogenesis is yet to be determined $[3,26]$.

In myositis associated with anti-Jo-1 antibodies and the antisynthetase syndrome, the inflammatory infiltrate consists of macrophages and $\mathrm{T}$ cells, and is mainly perimysial and perivascular in distribution, with sarcolemmal complement deposition and necrosis of perifascicular myofibres, and fragmentation and intense alkaline phosphatase staining of perimysial connective tissue $[27,28]$.

Humoral mechanisms are also thought to be involved in the NAM group of myopathies, which are etiologically heterogeneous. The best-characterized subgroups are those associated with serum autoantibodies to signal recognition peptide (antiSRP), or to 3-hydroxy-3-methyl-glutaryl-CoA reductase (anti-
HMGCR), the latter usually occurring in patients who have been on statin drugs, but may also occur in statin-naïve patients. NAM may also occur in the absence of these antibodies in patients with malignancy, connective tissue diseases, or viral infections [29]. The inflammatory infiltrate is usually absent or sparse but when present comprises mainly CD68+ macrophages, with a type I helper T cell (Th1)/M1 macrophage response in the muscle tissue [30]. There can be upregulation of MHC-I antigens in myofibers, particularly in cases associated with statin drug therapy $[31,32]$. In anti-SRPassociated cases a complement-dependent antibody-mediated mechanism has been implicated [33].

Traditionally the Th1-related cytokines tumor necrosis factor (TNF)- $\alpha$ and IFN- $\gamma$ are considered key pathogenic mediators in the IMIMs, and this has been the basis for trying cytokine-targeted therapies, such as the TNF- $\alpha$ inhibitors [4]. However, more recent studies have also implicated the Th17 pathway as an alternative pathogenic mechanism in PM and $\mathrm{DM}$, and have identified the strongly proinflammatory cytokine IL-17 and other Th17 cytokines such IL-22 and IL-6 as potentially novel therapeutic targets. In addition to their effects on the immune response, certain cytokines such as IL-17 and IL- $1 \alpha$ may also act directly on muscle tissue by activating signaling pathways such as nuclear factor kappa $\mathrm{B}$, leading to upregulated expression of MHC-I and production of cytokines and chemokines [34, 35]. In IBM there is evidence that proinflammatory cytokines such as IL-1 $\beta$ may contribute to the degenerative process in myofibers by leading to increased expression of amyloid precursor protein and cell stress proteins, and to the accumulation of amyloid proteins [36].

\section{DM, PM, and OS}

\section{Conventional Therapies}

Although their efficacy has never been confirmed in a randomized controlled trial (RCT), corticosteroids are the traditional first-line treatment for DM, PM, and OS once the diagnosis has been established and other disorders that can mimic an IMIM have been excluded $[6,37,38]$. It is usual to start treatment with oral prednisolone at a dose of $\sim 1 \mathrm{mg} / \mathrm{kg} / \mathrm{day}$ and it is preferable to avoid using higher doses because of the greater risk of steroid side effects. In patients with more severe weakness, and particularly if there is weakness of the bulbar or respiratory muscles, a quicker response may be achieved by starting treatment with intravenous methylprednisolone (3-5 pulses of $0.5-1.0 \mathrm{~g}$ ) and then continuing with oral prednisolone. Previous reviews have discussed the practical aspects of managing ongoing therapy and have emphasized the importance of not continuing high doses of steroids for too long and balancing this against not tapering the dose too quickly. They advocate the introduction of an immunosuppressive agent 
such as methotrexate, azathioprine, or mycophenolate earlier rather than later as a steroid-sparing strategy [34, 38-41]. Oral pulse therapy with dexamethasone (monthly cycles of $40 \mathrm{mg}$ / day for 4 consecutive days) has been suggested as an alternative to prednisolone and has been shown to be as effective in a RCT and to have a more favorable side effect profile, but the time to relapse was shorter with dexamethasone [42].

Few studies have compared the relative efficacy and side effect profiles of the different immunosuppressive agents in randomized myositis trials [43]. Overall, these studies have not shown evidence for superior efficacy of any of the commonly used drugs, namely methotrexate, azathioprine, mycophenolate, and ciclosporin. However, in view of the small numbers of subjects in these trials, further prospective studies in larger patient cohorts are still needed to provide a more reliable evidence base for the choice of first- and second-line immunosuppressive therapies in practice.

In some patients the myositis is unresponsive to corticosteroids and immunosuppressives, or is not adequately controlled. In such cases the diagnosis should first be revisited to ensure that other disorders such as dysferlinopathy and other forms of muscular dystrophies that can mimic an IMIM have been adequately excluded [37], before considering other therapeutic options such as switching or combining immunosuppressive agents, or a course of IVIG or rituximab (Fig. 1). A number of studies have investigated the possible mechanisms responsible for steroid resistance; however, at present there is no reliable way of predicting whether or not a patient will be responsive to steroids [44]. Ikezoe et al. [45] found that the numbers of endomysial CD8+ T cells that stained positively for the cytolytic molecule granulysin were higher in steroid- resistant PM cases than in steroid-responsive cases, and suggested that measurement of serum granulysin levels may be predictive of steroid responsiveness and prognosis. Steroid resistance may be related to increased survival of infiltrating $\mathrm{T}$ cells in muscle tissue, which has been linked to high mobility group protein B1-induced activation of autophagic mechanisms in T cells [46].

\section{IVIG}

The efficacy of IVIG as an add-on treatment in resistant cases of DM was demonstrated in a double-blind crossover trial [47, 48], and has also been confirmed in clinical practice. It has also been shown to be effective for the treatment of cases of drug-resistant PM, OS, and NAM, although its efficacy in these conditions has not been confirmed in a RCT [49]. The results of short-term (3-6-month) placebo-controlled trials of IVIG in IBM showed only minor functional benefits or temporary disease stabilization [50-52]; however, there have not been any longer-term studies and it is not known whether continued IVIG therapy would modify the course of the disease.

In current practice IVIG is reserved for treatment of more severe cases of DM, PM, OS, and NAM that are not adequately controlled with steroids and immunosuppressives, particularly if there are other associated problems such as interstitial lung disease or myocarditis, and for patients with severe relapses who have bulbar or respiratory muscle weakness. IVIG is thought to be particularly effective in statin-induced NAM [53], and is also an ideal alternative treatment option in patients with immunodeficiency [48], or those who have adverse
Fig. 1 Proposed schema for the use of currently available treatment modalities in immune-mediated inflammatory myopathies (IMIM). $\mathrm{IV}=$ intravenous; MTX = methotrexate; $\mathrm{AZA}=$ azathioprine; MMF = mycophenolate mofetil; ILD = interstitial lung disease; $\mathrm{DM}=$ dermatomyositis; $\mathrm{NAM}=$ necrotizing autoimmune myopathy

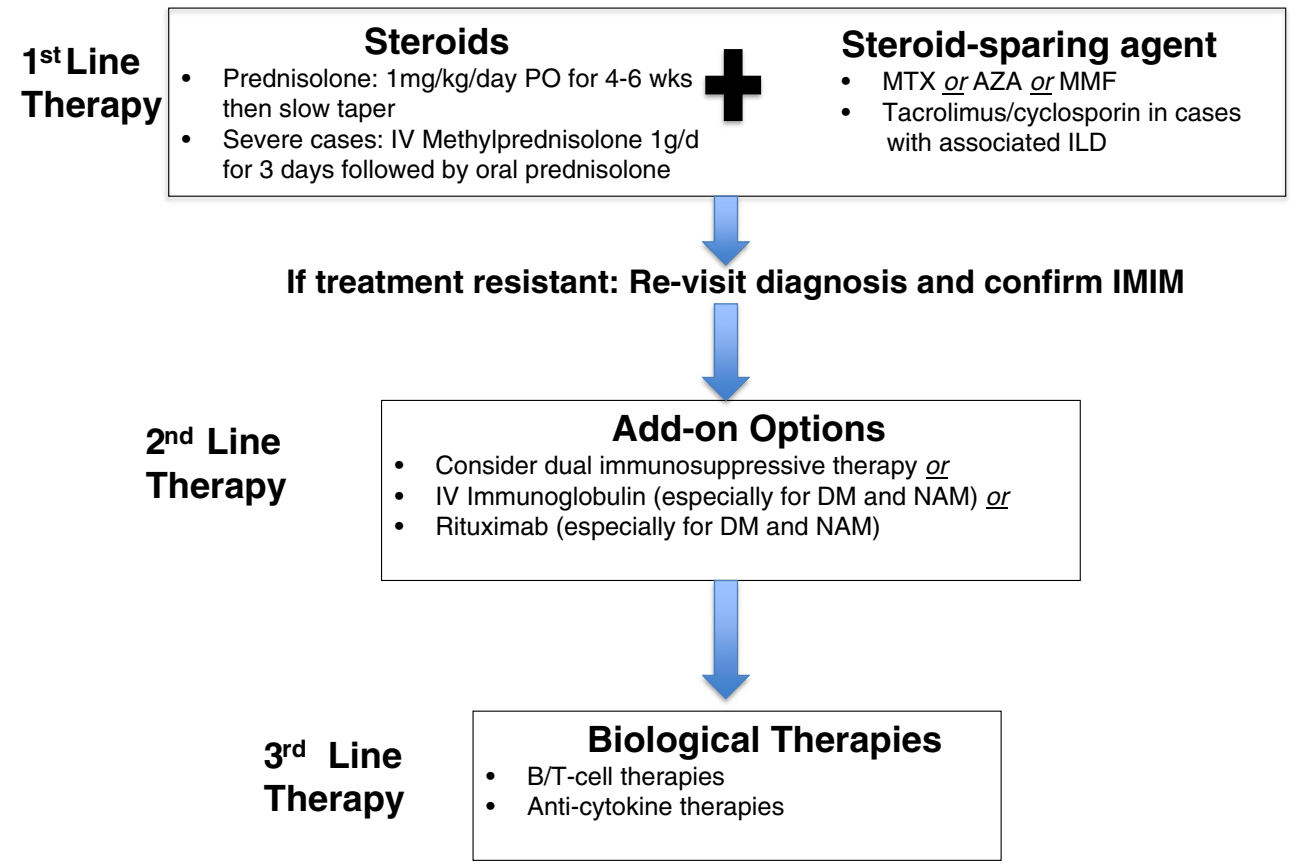


reactions to immunosuppressives, and in children or women of child-bearing age. It has also been used safely to treat myositis and other autoimmune disorders during pregnancy [54, 55].

A recent trial of GB-0998, which is polyethylene glycoltreated human IgG, in refractory PM/DM (NCT00335985) [56], found GB-0998 was well tolerated, and resulted in significant improvement in muscle strength, swallowing scores, and time to normalization of serum CK. However, there was also some improvement in the placebo group and the differences between the 2 patient groups were not significant. Several possible reasons were suggested for this, including low patient numbers and the possibility that the placebo group had a partial response to corticosteroids. A group of 7 patients (4 with DM, 3 with PM) were recently trialed on subcutaneous immunoglobulin, where significant benefits in muscle function and quality of life, as well as safety and tolerability, were demonstrated, suggesting that further trials should be undertaken $[57,58]$. There is also an ongoing clinical trial of subcutaneous immunoglobulin (Hizentra) for patients with DM (NCT02271165).

\section{Biologic Agents}

In patients who are still left with active disease and muscle weakness, despite high-dose steroids, steroid-sparing agents, and IVIG, or are intolerant of such therapies, there is a need for more targeted forms of immunotherapy. As the molecular mechanisms underlying the etiopathogenesis are still not fully understood, the targets for biological therapies have not yet been fully identified. However, we have entered a new era of specific therapies that target different arms of the immune system, such as selectively depleting B or T cells, and costimulatory and adhesion molecules and cytokines. Based on presumed immunopathogenic pathways, many clinicians have trialed these agents in IMIMs, and there have been multiple case reports where biological therapies have been effective in treating active myositis, leading to multiple trials of these therapies (Table 2). The use of these biological agents has revolutionized the treatment of other inflammatory conditions, including rheumatoid arthritis and Crohn's disease, and are usually well tolerated but come with potential risks, including infusion/injection reactions, infections including progressive multifocal encephalopathy [59], and tumors, particularly lymphoma. As we more fully understand the different subtypes of myositis and their distinct pathophysiological pathways, targeted therapies may well move to be first- or second-line therapy.

\section{B- and T-Cell Therapies}

A number of early case reports and case series reported positive effects of rituximab (an anti-CD20 monoclonal antibody that depletes B cells), on resistant PM and anti-SRP-associated disease [60-62]. There have also been many positive reports on the efficacy of rituximab in treatment-resistant DM [63-67]. These early reports led to an open-label study of rituximab for refractory PM [68]. Rituximab was found to be well tolerated and there was a trend towards a positive effect. This was followed by a randomized trial performed by Oddis et al. [69] in 200 patients with refractory PM and DM. They reported that $83 \%$ of randomized patients met the definition of improvement by around 20 weeks and that the treatment was well tolerated and had a significant steroidsparing effect over the 44-week study period, although the primary and secondary outcome measures were not achieved [69]. A recent retrospective review of the effectiveness of rituximab in 16 cases of refractory myositis reported a $50 \%$ response rate at 6 months, with the best response in patients with overlap myositis and the antisynthetase syndrome [70]. However, not all patients respond to rituximab [71, 72], and, as yet, it is not possible to identify which patients are likely to respond. Aggarwal et al. [73] analyzed data on 195 patients with myositis treated with rituximab to find predictors of response to treatment, and found the presence of antisynthetase (primarily anti-Jo-1) and anti-Mi-2 antibodies, juvenile DM, and a lower disease damage score (physician's global assessment) strongly predicted improvement with rituximab in patients with refractory myositis. Humanized forms of monoclonal anti-CD20 antibodies (e.g., ocrelizumab) may be better tolerated but have not yet been tried in myositis. In addition to rituximab, there is a current trial of belimumab, which is an inhibitor of B-cell activation (NCT02347891) in refractory immune-mediated myopathies.

Alemtuzumab, an anti-CD52 antibody that depletes T cells and mature monocytes, has been trialed in IBM but not in PM, DM or NAM [74]. However, there has been a single case report describing the efficacy of alemtuzumab in treatmentresistant PM [75]. Another T-cell inhibitor, abatacept, which blocks co-stimulation of $\mathrm{T}$ cells by inhibiting binding of the co-stimulatory protein CD28 expressed on effector T cells, has been reported to be effective in some case reports of refractory myositis [76-78]. A trial, "Abatacept Treatment in Polymyositis and Dermatomyositis" (ARTEMIS) (NCT01315938), was completed in 2013 but the results have not yet been published. BAF312 (fingolimod), a sphingosine 1-phosphate receptor modulator that functions as an immunomodulator trapping $\mathrm{T}$ cells in lymphoid organs, is currently being trialed in refractory PM (NCT01801917) and DM (NCT02029274). The drug leads to an $80 \%$ reduction in peripheral T-cell counts, and is in current use for the treatment of multiple sclerosis. Given the infiltration of T cells in PM and DM, and the recent success in other autoimmune disorders, the results of this trial are awaited with interest, and perhaps a trial of alemtuzumab should also be considered in treatmentresistant myositis. 
Table 2 Recent/current clinical trials in myositis with biologic therapies

\begin{tabular}{|c|c|c|c|c|}
\hline Name of drug & Mode of action & $\begin{array}{l}\text { Clinical trials identifier/trial } \\
\text { type/phase/patient number }\end{array}$ & Trial population & Results \\
\hline Belimumab & $\begin{array}{l}\text { Anti-B-cell-activating } \\
\text { factor Ab inhibits } \\
\text { B-cell activation }\end{array}$ & $\begin{array}{l}\text { NCT02347891 } \\
\text { Phase } 2 / 3 \\
\text { Multicenter, double-blind, } \\
\text { placebo-controlled } \\
\text { crossover } \\
\text { Aiming for } 60 \text { patients }\end{array}$ & Refractory IIMs & Recruiting \\
\hline Alemtuzumab & $\begin{array}{l}\text { Anti-CD52 Ab depleting } \\
\text { mature T cells and } \\
\text { monocytes }\end{array}$ & $\begin{array}{l}\text { NCT00079768 } \\
\text { Phase } 2 \\
\text { Interventional trial } \\
13 \text { patients }\end{array}$ & sIBM & $\begin{array}{l}\text { Slowed disease } \\
\text { progression, } \\
\text { improvement in some } \\
\text { patients, reduced } \\
\text { endomysial } \\
\text { inflammation and stress } \\
\text { molecules [74] }\end{array}$ \\
\hline Arimoclomol & $\begin{array}{c}\text { Amplifies heat shock } \\
\text { protein expression }\end{array}$ & $\begin{array}{l}\text { NCT00769860 } \\
\text { Phase 2a } \\
\text { Double-blind RCT } \\
24 \text { patients }\end{array}$ & sIBM & $\begin{array}{l}\text { Safe and well tolerated, and } \\
\text { a trend to slower decline } \\
\text { [138] }\end{array}$ \\
\hline $\begin{array}{l}\text { Rituximab } \\
\text { (FORCE study) }\end{array}$ & $\begin{array}{l}\text { Chimeric anti-CD20 Ab } \\
\text { (B-cell marker) }\end{array}$ & $\begin{array}{l}\text { NCT00774462 } \\
\text { Phase } 2 \\
\text { Open-label single } \\
\text { group assignment } \\
12 \text { patients }\end{array}$ & $\begin{array}{l}\text { Refractory IIMs with } \\
\text { specific antibodies and } \\
\text { myasthenia gravis }\end{array}$ & $\begin{array}{l}\text { Rituximab allowed a } \\
\text { reduction in } \\
\text { immunosuppressants in } \\
\text { around } 50 \% \text { of cases, } \\
\text { with benefit seen in } \\
\text { muscle strength, } \\
\text { arthralgia, and lung } \\
\text { disease. [139] }\end{array}$ \\
\hline Rituximab & $\begin{array}{l}\text { Chimeric anti-CD20 Ab } \\
\text { (B-cell marker) }\end{array}$ & $\begin{array}{l}\text { NCT00106184 } \\
\text { Phase } 2 \\
\text { Double-blind } \\
\text { Parallel assignment } \\
200 \text { patients }\end{array}$ & $\mathrm{DM}$ and $\mathrm{PM}$ & $\begin{array}{l}83 \% \text { improved over } 44 \\
\text { weeks and provided a } \\
\text { significant steroid- } \\
\text { sparing effect, but } \\
\text { primary and secondary } \\
\text { outcomes not met [69] }\end{array}$ \\
\hline $\begin{array}{l}\text { Rituximab vs } \\
\text { Cyclophosphamide } \\
\text { in ILD }\end{array}$ & $\begin{array}{l}\text { Chimeric anti-CD20 Ab } \\
\text { (B-cell marker) }\end{array}$ & $\begin{array}{l}\text { NCT01862926 } \\
\text { Phase 2/3 } \\
\text { Double-blind RCT } \\
\text { Estimated } 116\end{array}$ & $\begin{array}{l}\text { Interstitial lung disease } \\
\text { Scleroderma } \\
\text { IIM } \\
\text { MCTD }\end{array}$ & Recruiting \\
\hline $\begin{array}{l}\text { Follistatin gene } \\
\text { transfer }\end{array}$ & $\begin{array}{l}\text { Gene therapy trial to } \\
\text { deliver a gene to muscle } \\
\text { called follistatin (FS344) } \\
\text { that can build muscle } \\
\text { size and strength }\end{array}$ & $\begin{array}{l}\text { NCT01519349 } \\
\text { Phase } 1 \\
\text { Open-label single } \\
\text { group assignment } \\
\text { Aiming for } 15 \text { patients }\end{array}$ & $\begin{array}{l}\text { IBM and Becker } \\
\text { muscular dystrophy }\end{array}$ & $\begin{array}{l}\text { Enrolling by invitation } \\
\text { only }\end{array}$ \\
\hline Infliximab & Anti-TNF- $\alpha$ & $\begin{array}{l}\text { NCT00443222 } \\
\text { Phase } 2 / 3 \\
\text { Interventional single } \\
\text { group assignment } \\
13 \text { patients }\end{array}$ & $\begin{array}{l}\text { Refractory } \\
\text { PM/DM/sIBM }\end{array}$ & $\begin{array}{l}\text { Inflixmab not effective in } \\
\text { refractory IIMs [92] }\end{array}$ \\
\hline Infliximab & Anti-TNF- $\alpha$ & $\begin{array}{l}\text { NCT } 00033891 \\
\text { RCT } \\
18 \text { patients ( } 12 \text { treatment, } \\
6 \text { placebo) }\end{array}$ & Refractory PM/DM & $\begin{array}{l}\text { Well tolerated but only } \\
\text { limited efficacy in adult } \\
\text { refractory PM/DM [140] }\end{array}$ \\
\hline Infliximab & $\begin{array}{l}\text { Anti-TNF- } \alpha \text { and } \\
\text { Methotrexate }\end{array}$ & $\begin{array}{l}\text { Open-label trial } \\
6 \text { patients }\end{array}$ & $\begin{array}{c}\text { Drug-naïve recent } \\
\text { onset } \mathrm{PM} / \mathrm{DM}\end{array}$ & $\begin{array}{l}\text { Study terminated early } \\
\text { owing to low recruitment } \\
\text { and high disease } \\
\text { progression, but may be } \\
\text { a subgroup who respond } \\
\text { [91] }\end{array}$ \\
\hline Bimagrumab & $\begin{array}{l}\text { Humanized anti-activin II re- } \\
\text { ceptor } \mathrm{Ab} \text { to promote } \\
\text { muscle growth }\end{array}$ & $\begin{array}{l}\text { NCT01423110 } \\
\text { Phase } 2 \\
\text { Double-blind RCT } \\
14 \text { patients }\end{array}$ & sIBM & $\begin{array}{l}\text { Single infusion resulted in } \\
\text { increased thigh muscle } \\
\text { volume, lean body } \\
\text { mass and improved 6-min }\end{array}$ \\
\hline
\end{tabular}


Table 2 (continued)

\begin{tabular}{|c|c|c|c|c|}
\hline Name of drug & Mode of action & $\begin{array}{l}\text { Clinical trials identifier/trial } \\
\text { type/phase/patient number }\end{array}$ & Trial population & Results \\
\hline & & & & $\begin{array}{l}\text { walking distance } \\
{[141]}\end{array}$ \\
\hline Anakinra & $\begin{array}{l}\text { Anti-IL-1 } \\
\text { receptor antagonist }\end{array}$ & $\begin{array}{l}\text { NCT01165008 } \\
\text { Phase } 2 / 3 \\
\text { Interventional single group } \\
\text { assignment } \\
15 \text { patients }\end{array}$ & $\begin{array}{l}\text { Refractory } \\
\text { PM/DM/sIBM }\end{array}$ & $\begin{array}{c}7 \text { improved, (3 DM, } 3 \text { PM, } \\
1 \text { sIBM), } 5 \text { unchanged, } \\
\text { and } 3 \text { worsened. Results } \\
\text { need to be confirmed in } \\
\text { larger studies }[96,142]\end{array}$ \\
\hline Anakinra & $\begin{array}{l}\text { Anti-IL-1 } \\
\text { receptor antagonist }\end{array}$ & $\begin{array}{l}\text { Kosmidis et al. [137] } \\
\text { Phase } 2 \\
\text { Single group assignment } \\
4 \text { patients }\end{array}$ & sIBM & $\begin{array}{l}\text { No improvement in grip } \\
\text { strength in any patient } \\
{[137]}\end{array}$ \\
\hline Etancercept & Anti-TNF- $\alpha$ & $\begin{array}{l}\text { NCT00802815 } \\
\text { Phase } 0 \\
\text { Double-blind } \\
\text { RCT } \\
\text { Aimed for } 20 \text { patients }\end{array}$ & sIBM & No results found \\
\hline Etancercept & Anti-TNF- $\alpha$ & $\begin{array}{l}\text { Phase } 2 \\
\text { Single group allocation } \\
9 \text { patients, } 34 \text { controls }\end{array}$ & sIBM & $\begin{array}{l}\text { No statistical difference } \\
\text { between treatment group } \\
\text { and natural history group } \\
\text { except small } \\
\text { improvement grip } \\
\text { strength at } 12 \text { months } \\
\text { [143] }\end{array}$ \\
\hline Etanercept & Anti-TNF- $\alpha$ & $\begin{array}{l}\text { NCT00112385 } \\
\text { Phase } 1 \\
\text { Double-Blind } \\
\text { RCT } \\
16 \text { patients (11 Etanercept, } 5 \\
\text { placebo) }\end{array}$ & $\mathrm{DM}$ & $\begin{array}{l}\text { Significant steroid-sparing } \\
\text { effect and longer time to } \\
\text { relapse [94] }\end{array}$ \\
\hline $\begin{array}{l}\text { Autologous stem cell } \\
\text { transplant }\end{array}$ & & $\begin{array}{l}\text { NCT00278564 } \\
\text { Phase } 1 \\
\text { Open-label } \\
\text { Single group assignment } \\
\text { Aiming for } 10 \text { patients }\end{array}$ & $\mathrm{DM} / \mathrm{PM} / \mathrm{OS}$ & Currently recruiting \\
\hline $\begin{array}{l}\text { BAF312 } \\
\text { (Fingolimod) }\end{array}$ & $\begin{array}{l}\text { Sphingosine 1-phosphate } \\
\text { receptor modulator } \\
\text { which functions as an im- } \\
\text { munomodulator } \\
\text { trapping T cells in } \\
\text { lymphoid organs }\end{array}$ & $\begin{array}{l}\text { NCT01148810 } \\
\text { Phase } 2 \text { study } \\
\text { Double-blind } \\
\text { RCT } \\
29 \text { patients }\end{array}$ & $\begin{array}{r}\text { Refractory } \\
\text { DM/PM }\end{array}$ & Study terminated \\
\hline $\begin{array}{l}\text { BAF312 } \\
\text { (Fingolimod) }\end{array}$ & As above & $\begin{array}{l}\text { NCT01801917 } \\
\text { Phase } 2 \\
\text { Double-blind } \\
\text { RCT } \\
\text { Aiming for } 30 \text { patients }\end{array}$ & Refractory PM & Currently recruiting \\
\hline $\begin{array}{l}\text { BAF312 } \\
\text { (Fingolimod) }\end{array}$ & As above & $\begin{array}{l}\text { NCT02029274 } \\
\text { Phase } 2 \\
\text { Double-blind } \\
\text { RCT } \\
\text { Aiming } 56 \text { patients }\end{array}$ & Refractory DM & Currently recruiting \\
\hline $\begin{array}{l}\text { H5G1.1-mAb } \\
\text { (Eculizumab) }\end{array}$ & $\begin{array}{l}\text { Anti-C5 (complement 5) } \\
\text { Monoclonal antibody } \\
\text { preventing cleavage } \\
\text { into C5a and C5b } \\
\text { fragments }\end{array}$ & $\begin{array}{l}\text { NCT00005571 } \\
\text { Phase } 2 \\
\text { Third-party blind } \\
\text { RCT } \\
\text { Aimed for } 15 \text { patients }\end{array}$ & Refractory DM & Unable to find results \\
\hline $\begin{array}{l}\text { Abatacept } \\
\text { (ARTEMIS) }\end{array}$ & $\begin{array}{l}\text { Inhibits co-stimulation } \\
\text { of T cells }\end{array}$ & $\begin{array}{l}\text { NCT01315938 } \\
\text { Phase } 2 \\
\text { Single group assignment } \\
\text { Aimed for } 20 \text { patients }\end{array}$ & $\begin{array}{l}\text { Refractory } \\
\mathrm{PM} / \mathrm{DM}\end{array}$ & $\begin{array}{l}\text { Trial completed but no } \\
\text { results found }\end{array}$ \\
\hline Hizentra & Subcutaneous IVIG & NCT02271165 & DM & Ongoing \\
\hline
\end{tabular}


Table 2 (continued)

\begin{tabular}{|c|c|c|c|c|}
\hline Name of drug & Mode of action & $\begin{array}{l}\text { Clinical trials identifier/trial } \\
\text { type/phase/patient number }\end{array}$ & Trial population & Results \\
\hline & & $\begin{array}{l}\text { Phase } 0 \\
\text { Open-label } \\
\text { Aiming for } 10 \text { patients }\end{array}$ & & \\
\hline Apremilast & $\begin{array}{l}\text { Selective phosphodiesterase } \\
4 \text { inhibitor }\end{array}$ & $\begin{array}{l}\text { NCT01140503 } \\
\text { Phase } 2 \\
\text { Open-label, single group } \\
\text { assignment } \\
\text { Aimed for } 5 \text { patients }\end{array}$ & $\begin{array}{l}\text { Cutaneous } \\
\text { manifestations DM }\end{array}$ & $\begin{array}{l}\text { Study terminated owing } \\
\text { to low recruitment }\end{array}$ \\
\hline GB-0998 & $\begin{array}{l}\text { Polyethylene glycol- } \\
\text { treated human IgG }\end{array}$ & $\begin{array}{l}\text { NCT00335985 } \\
\text { Phase } 3 \\
\text { Double-blind RCT } \\
26 \text { patients } \\
\quad(16 \mathrm{PM}, 10 \mathrm{DM})\end{array}$ & Refractory DM/PM & $\begin{array}{l}\text { Significant improvement } \\
\text { in endpoints for both } \\
\text { treatment and placebo } \\
\text { groups, without } \\
\text { significant difference } \\
\text { between groups [56] }\end{array}$ \\
\hline Tocilizumab & Anti-IL-6 Ab & $\begin{array}{l}\text { NCT02043548 } \\
\text { Phase } 2 \\
\text { Double-blind } \\
\text { RCT } \\
\text { Aiming for } 40 \text { patients }\end{array}$ & $\begin{array}{l}\text { Refractory } \\
\mathrm{DM} / \mathrm{PM}\end{array}$ & Currently recruiting \\
\hline Gevokizumab & Anti-IL-1 $\beta$ & $\begin{array}{l}\text { EudraCT number } \\
\text { 2012-005772-34 }\end{array}$ & $\mathrm{PM} / \mathrm{DM} / \mathrm{NAM}$ & Currently recruiting \\
\hline $\begin{array}{l}\text { Sifalimumab } \\
\text { (MEDI-545) }\end{array}$ & Anti-IFN- $\alpha$ Ab & $\begin{array}{l}\text { NCT00533091 } \\
\text { Phase 1b study } \\
\text { Double-blind } \\
\text { RCT } \\
26 \text { PM, } 25 \text { DM patients }\end{array}$ & $\mathrm{PM} / \mathrm{DM}$ & $\begin{array}{l}\text { Suppression of IFN in blood } \\
\text { and muscle } \\
\text { and some clinical } \\
\text { improvement }[144]\end{array}$ \\
\hline
\end{tabular}

$A b$ antibody, IIM idiopathic inflammatory myopathy, $S I B M$ sporadic inclusion body myositis, $R C T$ randomized controlled trial, $D M$ dermatomyositis, $P M$ polymyositis, $M C T D$ mixed connective tissue disease, $I B M$ inclusion body myositis, $T N F$ tumor necrosis factor, $I V I G$ intravenous immunoglobulin, $N A M$ necrotizing autoimmune myopathy, IFN interferon

\section{Cytokine-Based Therapies}

There are elevated levels of soluble TNF receptors and TNF- $\alpha$ in the serum of patients with active PM and DM [79]; however, there are conflicting reports in the literature about the efficacy of TNF- $\alpha$ inhibitors in the treatment of myositis. While early case series reported positive effects [80-86], there has been increasing concern over these drugs due to some recent reports of disease flares or the initiation of myositis with TNF- $\alpha$ therapies [87-90]. An open-label study looking at the efficacy of infliximab combined with methotrexate was terminated owing to a low inclusion rate and a high dropout rate due to disease progression or side effects [91]. Another open-label study of infliximab performed in 13 patients with refractory DM/PM/IBM found no patients improved in muscle strength, measured by manual muscle testing, and several patients actually worsened [92]. A study of etanercept in active DM did not show any initial improvement until an additional drug (methotrexate or azathioprine) was added [93]. However, a recent RCT of etanercept in active DM showed it was well tolerated [94], and the etancercept-treated group had a longer time to treatment failure and a lower mean prednisolone dose. This may suggest that subgroups of patients might respond to this class of drug, but predictors of response to the TNF- $\alpha$ inhibitors are not yet known, and, in general, they are not currently recommended in the treatment of active myositis.

Interleukin (IL)- $1 \alpha$ and IL- $\beta$ have been shown to be upregulated in muscle tissue from patients with PM, DM, and IBM [95]. An open-label trial was performed with an IL-1 blocking agent (anakinra, $100 \mathrm{mg}$ s.c. daily) to assess efficacy and tolerability in a cohort of 15 treatment-resistant patients with PM $(n=6), \mathrm{DM}(n=4)$ and IBM $(n=5)$ [96]. They found improvement in 7 patients ( 3 with PM, 3 with DM, and 1 with IBM), 5 were unchanged and 3 worsened, which correlated somewhat with IL-1Ra (receptor antagonist) expression in post-treatment biopsies, which may warrant further investigation in a larger placebo-controlled trial. A trial of gevokizumab (an anti-IL-1 $\beta$ monoclonal antibody) is currently recruiting patients with refractory $\mathrm{PM} / \mathrm{DM}$ and NAM (EudraCT number 2012-005772-34).

IL-6 plays a role in antibody production and the release of acute-phase proteins $[97,98]$. There has been a report published of 2 patients with refractory PM responding well to tocalizumab, a monoclonal antibody to IL-6 [99]. In addition to blocking Il-6, tocalizumab is also believed to have other 
immunomodulatory effects, which may predict effectiveness in myositis [100, 101]. IL-6 blockade has also been shown to be effective in mouse models of myositis [102]. This agent is currently under trial in refractory DM/PM (NCT02043548).

DM is thought to be a humorally mediated attack on muscle and skin with the early deposition of membrane attack complex on capillaries in both skin and muscle. Eculizumab (an anti-C5 monoclonal antibody that prevents cleavage into $\mathrm{C} 5 \mathrm{a}$ and $\mathrm{C} 5 \mathrm{~b}$ and formation of the membrane attack complex) has been trialed in 15 cases of refractory DM (NCT00005571) with some positive indications for response, and warrants further evaluation [103].

In addition, there is overexpression of IFN-inducible genes in active myositis, particularly in DM, which likely contributes to myofiber injury $[104,105]$. Therefore, MEDI-545 (Sifalimumab), an anti-IFN- $\alpha$ monoclonal antibody, was trialed in refractory PM/DM (NCT00533091). This phase 1B study found suppression of IFN in blood and muscle and some clinical improvement, suggesting that further studies may be worthwhile [106].

\section{Other Treatments}

Adrenocorticotropic hormone (ACTH) gel is a currently approved but not often used treatment for active myositis. ACTH gel is reported to have steroidogenic and antiinflammatory effects, as well as immunomodulatory properties via its interaction with the melanocortin receptors in immune effector cells, and has been reported to be effective in nephrotic syndrome, and exacerbations of multiple sclerosis and systemic lupus erthythematosus [107, 108]. A trial of 80 $\mathrm{U}(1 \mathrm{ml})$ twice weekly in 4 patients with DM/PM, and once weekly in 1 patient for 12 weeks was carried out. All patients tolerated the treatment well, and had improved muscle strength and reduced pain, and skin involvement cleared [109]. Although this was a retrospective case series in patients who were also on other therapies, given the tolerability and possible efficacy, a further prospective trial should be considered.

In severe autoimmune disorders, autologous stem cell transplantation is another therapeutic option that has been considered. There has been a report of a patient with refractory anti-SRP-associated myositis who responded to myeloablative cyclophosphamide and total body irradiation, with normalization of $\mathrm{CK}$ levels and improvement in muscle strength, which was sustained for 3 years [110]. In addition, a sustained response was also achieved in 2 patients with severe refractory juvenile DM after conditioning with fludarabine, cyclophosphamide, and antithymocyte globulin [111]. There is currently a trial of autologous stem cell transplantation recruiting for refractory PM/DM/JDM and OS (NCT00278564).
Mesenchymal stem cells have some immunosuppressive effects and have little immunogenicity, and have also been trialed in a group of 10 patients with refractory $\mathrm{PM} / \mathrm{DM}$ [112]. These allogeneic mesenchymal stem cells were obtained from bone marrow or umbilical cord, and are in current use for treating steroid-resistant graft-versus-host disease. Two patients died within 6 months. The deaths were associated with infections and disease recurrence leading to myocarditis and heart failure. The remaining patients had a reduction in their prednisolone dose and CK levels, and some improvement in muscle strength, suggesting that this form of treatment may be worth considering in patients who are resistant to all other forms of therapy.

Plasma exchange is thought to be helpful in removing autoreactive antibodies. Therefore, in some forms of IMIM, such as those associated with the anti-SRP or anti-HMGCR antibodies, there may be a theoretical role for such treatment. An early open-label study of patients with refractory PM/DM appeared positive [113], but a later randomized blinded trial was negative [114]. It may be useful to re-examine this in particular subtypes of myositis where antibodies are playing an important role, as there have been subsequent reports of benefit in a patient with DM and interstitial lung diseases (ILD) [115].

It has been postulated, on the basis of low serum levels of vitamin D, particularly early in the course of disease, compared with normal controls, that low vitamin D may be a risk factor for the development of inflammatory myopathies [116]. Moreover, there is a significantly higher frequency of autoantibodies, including anti- ANA (antinuclear antibody) and antiSRP, in vitamin D-deficient patients [117, 118]. Vitamin D supplementation and vitamin D receptor agonists are being increasingly explored in autoimmune diseases, including the inflammatory myopathies [119], as they particularly seem to target Th1-mediated inflammation [120]. This is a future direction worth exploring in inflammatory myopathies as an adjunct to other immunosuppressive treatment.

Recent studies have also shown that aerobic and resistance exercise programs can be beneficial in IMIMs when carried out in combination with immunotherapy and can improve aerobic performance and functional capacity [121, 122]. Oral creatine supplements have also been shown to improve muscle function [123].

\section{NAM}

NAM was only separated from PM by the muscle study group in 2004 [124], and is now recognized as a distinct form of IMIM. In contrast to DM and PM, there have not been any RCTs of immunotherapies in NAM, and the current approach to treatment is similar to that in PM and DM and is based largely on published case reports and case series. It is increasingly recognized that many patients with NAM are more 
resistant to conventional therapies than most cases of DM and PM. Few patients are fully controlled with corticosteroids alone and other options such as IVIG and biologic therapies are often required in patients who fail traditional first-line therapies [125]. While the majority of patients with antiHMGCR-associated NAM respond satisfactorily to a combination of prednisolone and an immunosuppressant such as methotrexate, there is a high frequency of relapse when the treatment is tapered or withdrawn, and many patients require treatment with IVIG or other therapies [31, 126, 127]. It is of interest that patients who had been exposed to statins were more likely to respond to treatment, whereas statin-naïve patients were more resistant, even with aggressive immunosuppressive treatment [127].

In anti-SRP-associated NAM the response to treatment is also variable. In the largest series of cases reported to date, of 84 patients who received prednisolone and were followed over a 2-year period, $62(77 \%)$ required additional therapies including IVIG, IV methylprednisolone, oral immunosuppressive agents, or IV cyclophosphamide [128]. A good response to treatment was noted in $32 \%$ of cases, whereas $45 \%$ showed only a partial response and required long-term immunotherapy, and $12 \%$ had only a minimal response and continued to deteriorate. In a series of 8 cases of anti-SRP-associated NAM, 6 patients who were refractory to standard immunosuppressive therapy were treated with rituximab and showed improved muscle strength, decline in CK levels, and reduced corticosteroid dose requirements, with an associated drop in anti-SRP antibody titers [129].

\section{IBM}

In spite of the T-cell-predominant inflammatory infiltrate and the strong evidence for an immune basis for the disease, the majority of cases of IBM fail to respond to conventional forms of immunotherapy or, at best, show only a temporary response, and none of the currently available therapies appear to alter the eventual course of the disease. The use of corticosteroids and other immune therapies in IBM has been largely empirical and there have been few RCTs of immunosuppressive agents or other therapies [50-52].

\section{Immunosuppressive Therapies}

An early open-label trial showed that although treatment with prednisolone and immunosuppressants reduced serum CK levels and muscle inflammation it did not prevent progression in the clinical course of the disease and degenerative changes in muscle biopsies [130]. A later study of repeat muscle biopsies in patients treated with IVIG and prednisolone showed that although the levels of a number of proinflammatory chemokines and cytokines and of ubiquitin and $\beta$-amyloid were reduced after treatment, TNF- $\alpha$ and mediators of nitrosative stress such as inducible nitric oxide synthase and nitrotyrosine were not reduced [131]. These findings indicate that immunosuppression per se is not sufficient to reverse all of the changes in IBM muscle and that the degenerative component of the disease persists even if the inflammation is suppressed. A similar conclusion is suggested by the results of the 2 small trials of T-cell depletion, initially using anti-T-lymphocyte globulin and subsequently alemtuzumab [74, 132], which showed a possible slowing in the rate of disease progression, although this needs to be confirmed in larger groups of patients. In the case of the anti-Tlymphocyte globulin trial there was a suggestion that combining T-cell depletion and immunosuppression with methotrexate may be more effective. In our experience of 2 patients treated with alemtuzumab, the potential minor benefits of such therapies need to be balanced against the risks of adverse effects such as severe infections (F Mastaglia and M Needham, unpublished).

\section{IVIG}

There have been a number of studies to evaluate the efficacy of IVIG in IBM, including 3 short-term placebo-controlled crossover trials [50-52]. The first of these was a 6-month study in which 19 patients with IBM received either IVIG or placebo for 3 months. Although the overall results were not conclusive, swallowing function improved on IVIG and there were improvements in muscle strength, particularly in some lower limb muscle groups [50]. In keeping with these findings, a second crossover study in which 22 patients with IBM received either IVIG or placebo in combination with their previous immunosuppressant medications for periods of 6 months concluded that there were mild functional improvements and apparent disease stabilization in the majority of patients over the 12-month period of the study [52]. A further study compared the efficacy of combined IVIG plus high-dose prednisone versus placebo plus prednisone, and found no significant changes in muscle strength, although repeat muscle biopsies showed a significant reduction in numbers of necrotic fibres in the IVIG randomized group [51]. In a recent uncontrolled follow-up study of 16 patients with IBM who received up to 20 IVIG infusions in combination with their regular immunosuppressive medications and were followed for a mean period of 23 months, improvement in swallowing and in quadriceps muscle strength, and serum CK reductions of $>$ $20 \%$ were noted in some patients but were not sustained at the end of the follow-up period [133]. The findings of these studies suggest that IVIG can have an impact on the disease process, which appears to vary in different muscle groups and in different patients. However, it remains to be determined whether more prolonged maintenance IVIG therapy can 
prevent the progression of the disease if it is started at an early stage in combination with immunosuppression.

\section{Cytokine-Based Therapies}

So far, there have been few studies of cytokine-based therapies in IBM. Two randomized controlled studies of $\beta$-IFN-1a in a low and high dose failed to demonstrate any significant benefit $[134,135]$. A small open trial of the TNF- $\alpha$ blocker etanercept in a group of 9 patients with IBM treated for an average of 17 months showed a small but significant improvement in hand grip strength at 12 months compared with a natural history cohort of patients and may warrant further evaluation in a controlled trial [136]. A small pilot study of the IL-1 receptor antagonist anakinra administered to 4 patients with longstanding IBM for a mean period of 7.7 months did not demonstrate any improvement in muscle strength or disease stabilization [137]. However, as in the case of IVIG it is possible that these cytokine-based therapies may be more effective if they are given at an earlier stage of the disease and over a longer timeframe.

\section{Therapeutic Approach in the Clinic}

Given the lack of a sound evidence base the use of these therapies in practice remains empirical. The authors recommend a 6-12-month trial of combined prednisolone and methotrexate selectively, particularly in patients whose disease is diagnosed early, or if there is a co-existing autoimmune disease such as Sjögren's syndrome or a connective tissue disease, and if the muscle biopsy shows prominent inflammation, with careful monitoring for steroid side effects, especially steroid myopathy. In our experience $\sim 20 \%$ of patients show an initial improvement or stabilization in muscle strength and are then continued on a maintenance immunosuppressive regimen. In patients with more rapidly progressive weakness or prominent dysphagia, a 3-6-month trial of monthly IVIG is recommended followed by a monthly maintenance regimen in patients who respond.

\section{Concluding Remarks}

The current approach to the treatment of IMIMs is still largely empirical and further RCTs are needed to provide a better evidence base for the use of immunosuppressive agents and other therapies in resistant cases of PM, DM, OS, and NAM. There is also a need for further trials of these therapies in IBM to determine whether certain subgroups of patients are more likely to respond if they are treated at an early stage of the disease, and if progression of the disease can be prevented if IVIG is administered over longer periods in combination with other forms of immunotherapy. The use of biologics in IMIM is still in its infancy and further multicenter trials of B- and Tcell depletion are required to determine the role of these therapies in resistant cases. In addition, the role of therapies targeting key cytokines involved in the pathogenesis of the different forms of myositis warrants further investigation, including approaches directed at proinflammatory cytokines such as IL-17, which are proving to be effective in other autoimmune diseases [35].

Acknowledgments We thank our colleagues Dr. P. Zilko, Dr. P. Hollingsworth, Dr. B. Phillips, and Ms. S. Walters at the Myositis Clinic at the West Australian Neuroscience Research Institute, and Dr. V. Fabian and Dr. R. Junkerstorff for providing muscle pathology diagnosis in our patients.

Required Author Forms Disclosure forms provided by the authors are available with the online version of this article.

\section{References}

1. Liang C, Needham M. Necrotizing autoimmune myopathy. Curr Opin Rheumatol 2011;23:612-619.

2. Dalakas MC. Pathogenesis and therapies of immune-mediated myopathies. Autoimmun Rev 2012;11:203-206.

3. Luo YB, Mastaglia FL. Dermatomyositis, polymyositis and immune-mediated necrotising myopathies. Biochim Biophys Acta 2015;1852:622-632.

4. Moran EM, Mastaglia FL. Cytokines in immune-mediated inflammatory myopathies: cellular sources, multiple actions and therapeutic implications. Clin Exp Immunol 2014;178:405-415.

5. Needham M, Mastaglia FL. Inclusion body myositis: current pathogenetic concepts and diagnostic and therapeutic approaches. Lancet Neurol 2007;6:620-631.

6. Dalakas MC. Mechanisms of disease: signaling pathways and immunobiology of inflammatory myopathies. Nat Clin Pract Rheumatol 2006;2:219-227.

7. van de Vlekkert J, Hoogendijk JE, de Visser M. Long-term follow-up of 62 patients with myositis. J Neurol 2014;261:992-998.

8. Troyanov Y, Targoff IN, Tremblay JL, Goulet JR, Raymond Y, Senecal JL. Novel classification of idiopathic inflammatory myopathies based on overlap syndrome features and autoantibodies: analysis of 100 French Canadian patients. Medicine (Baltimore) 2005;84:231-249.

9. Pestronk A, Kos K, Lopate G, Al-Lozi MT. Brachio-cervical inflammatory myopathies: clinical, immune, and myopathologic features. Arthritis Rheum 2006;54:1687-1696.

10. Rojana-Udomsart A, Fabian V, Hollingsworth PN, Walters SE, Zilko PJ, Mastaglia FL. Paraspinal and scapular myopathy associated with scleroderma. J Clin Neuromuscul Dis 2010;11:213222.

11. Allenbach Y, Benveniste O. Diagnostic utility of auto-antibodies in inflammatory muscle disease. J Neuromuscul Dis 2015;2:1325.

12. Oskarsson B. Myopathy: five new things. Neurology 2011;76: S14-S19.

13. Larman HB, Salajegheh M, Nazareno R, et al. Cytosolic 5'nucleotidase $1 \mathrm{~A}$ autoimmunity in sporadic inclusion body myositis. Ann Neurol 2013;73:408-418.

14. Pluk H, van Hoeve BJ, van Dooren SH, et al. Autoantibodies to cytosolic 5 '-nucleotidase $1 \mathrm{~A}$ in inclusion body myositis. Ann Neurol 2013;73:397-407. 
15. Herbert MK, Stammen-Vogelzangs J, Verbeek MM, et al. Disease specificity of autoantibodies to cytosolic 5'-nucleotidase $1 \mathrm{~A}$ in sporadic inclusion body myositis versus known autoimmune diseases. Ann Rheum Dis 2015 Feb 24 [Epub ahead of print].

16. Arahata K, Engel AG. Monoclonal antibody analysis of mononuclear cells in myopathies. V: identification and quantitation of T8+ cytotoxic and T8+ suppressor cells. Ann Neurol 1988;23:493-499.

17. Goebels N, Michaelis D, Engelhardt M, et al. Differential expression of perforin in muscle-infiltrating $\mathrm{T}$ cells in polymyositis and dermatomyositis. J Clin Invest 1996;97:2905-2910.

18. Dalakas MC. Pathogenesis of immune-mediated neuropathies. Biochim Biophy Acta 2015;1852:658-666.

19. De Paepe B, Creus KK, De Bleecker JL. Role of cytokines and chemokines in idiopathic inflammatory myopathies. Curr Opin Rheumatol 2009;21:610-616.

20. Fasth AE, Dastmalchi M, Rahbar A, et al. T cell infiltrates in the muscles of patients with dermatomyositis and polymyositis are dominated by CD28null T cells. J Immunol 2009;183:4792-4799.

21. Amemiya K, Granger RP, Dalakas MC. Clonal restriction of T-cell receptor expression by infiltrating lymphocytes in inclusion body myositis persists over time. Studies in repeated muscle biopsies. Brain 2000;123:2030-2039.

22. Benveniste O, Herson S, Salomon B, et al. Long-term persistence of clonally expanded T cells in patients with polymyositis. Ann Neurol 2004;56:867-872.

23. Salajegheh M, Rakocevic G, Raju R, Shatunov A, Goldfarb LG, Dalakas MC. T cell receptor profiling in muscle and blood lymphocytes in sporadic inclusion body myositis Neurology 2007;69: 1672-1679.

24. Van de Vlekkert J, Hoogendiijk JE, de Visser M. Myositis with endomysial cell invasion indicates inclusion body myositis even if other criteria are not fulfilled. Neuromuscul Disord 2015;25:451456.

25. Greenberg SA. Proposed immunologic models of the inflammatory myopathies and potential therapeutic implications. Neurology 2007;69:2008-2019.

26. Casciola-Rosen L, Mammen AL. Myositis autoantibodies. Curr Opin Rheumatol 2012;24:602-608.

27. Mescam-Mancini L, Allenbach Y, Hervier B, et al. Anti-Jo-1 antibody-positive patients show a characteristic necrotizing perifascicular myositis. Brain 2015;138:2485-2492.

28. Pestronk A. Immune and inflammatory myopathies: pathologic classification. Curr Opin Rheumatol 2014;23:595-604.

29. Stenzel W, Goebel HH, Aronica E. Review: immune-mediated necrotizing myopathies - a heterogeneous group of diseases with specific myopathological features. Neuropathol Appl Neurobiol 2012;38:632-646.

30. Preusse C, Goebel HH, Held J, et al. Immune-mediated necrotizing myopathy is characterized by a specific Th1-M1 polarized immune profile. Am J Pathol 2012;181:2161-2171.

31. Needham M, Fabian V, Knezevic W, Panegyres P, Zilko P, Mastaglia FL. Progressive myopathy with up-regulation of MHC-I associated with statin therapy. Neuromuscul Disord 2007;17:194-200.

32. Rodriguez Cruz PM, Luo YB, Miller J, Junckerstorff RC, Mastaglia FL, Fabian V. An analysis of the sensitivity and specificity of MHC-I and MHC-II immunohistochemical staining in muscle biopsies for the diagnosis of inflammatory myopathies. Neuromuscul Disord 2014;24:1025-1035.

33. Rojana-udomsart A, Mitrpant C, Bundell C, et al. Complementmediated muscle cell lysis: a possible mechanism of myonecrosis in anti-SRP associated necrotizing myopathy (ASANM). J Neuroimmunol 2013;264:65-70.

34. Dalakas MC. Therapeutic targets in patients with inflammatory myopathies: present approaches and a look to the future. Neuromuscul Disord 2006;16:223-236.
35. Moran EM, Mastaglia FL. The role of interleukin-17 in immunemediated inflammatory myopathies and possible therapeutic implications. Neuromuscul Disord 2014;24:943-952.

36. Schmidt J, Barthel K, Wrede A, Salajegheh M, Bahr M, Dalakas MC. Interrelation of inflammation and APP in SIBM: IL-1 beta induces accumulation of beta-amyloid in skeletal muscle. Brain 2008;131:1228-1240.

37. Mastaglia F. What to do when the treatment does not work: polymyositis. Pract Neurol 2008;2008:170-174.

38. Carstens PO, Schmidt J. Diagnosis, pathogenesis and treatment of myositis: recent advances. Clin Exp Immunol 2014;175:349-358.

39. Mastaglia FL, Phillips BA, Zilko P. Treatment of inflammatory myopathies. Muscle Nerve 1997;20:651-664.

40. Mastaglia FL, Phillips BA, Zilko PJ. Inflammatory myopathy. Curr Treat Options Neurol 1999;1:263-272.

41. Mastaglia FL, Zilko PJ. Inflammatory myopathies: how to treat the difficult cases. J Clin Neurosci 2003;10:99-101.

42. van de Vlekkert J, Hoogendijk JE, de Haan RJ, et al. Oral dexamethasone pulse therapy versus daily prednisolone in sub-acute onset myositis, a randomised clinical trial. Neuromuscul Disord 2010;20:382-389.

43. Gordon PA, Winer JB, Hoogendijk JE, Choy EH. Immunosuppressant and immunomodulatory treatment for dermatomyositis and polymyositis. Cochrane Database Syst Rev 2012;8:CD003643.

44. Nirmalananthan N, Hanna MG. Predicting steroid response in muscle disease. J Neurol Neurosurg Psychiatry 2006;77:11041105 .

45. Ikezoe K, Ohshima S, Osoegawa M, et al. Expression of granulysin in polymyositis and inclusion-body myositis. $\mathrm{J}$ Neurol Neurosurg Psychiatry 2006;77:1187-1190.

46. Zong M, Jorholt J, Winter J, Lindroos E, Harris H, IL. Autophagy may contribute to glucocorticoid resistance in myositis patients by maintaining muscle T cells homeostasis. Ann Rheum Dis 2014;73(Suppl 1):A85-86.

47. Dalakas MC, Illa I, Dambrosia JM, et al. A controlled trial of highdose intravenous immune globulin infusions as treatment for dermatomyositis. N Engl J Med 1993;329:1993-2000.

48. Dalakas MC. Controlled studies with high-dose intravenous immunoglobulin in the treatment of dermatomyositis, inclusion body myositis, and polymyositis. Neurology 1998;51:S37-S45.

49. Mastaglia FL, Phillips BA, Zilko PJ. Immunoglobulin therapy in inflammatory myopathies. J Neurol Neurosurg Psychiatry 1998;65:107-110.

50. Dalakas MC, Sonies B, Dambrosia J, Sekul E, Cupler E, Sivakumar K. Treatment of inclusion-body myositis with IVIg: a double-blind, placebo-controlled study. Neurology 1997;48: 712-716.

51. Dalakas MC, Koffman B, Fujii M, Spector S, Sivakumar K, Cupler E. A controlled study of intravenous immunoglobulin combined with prednisone in the treatment of IBM. Neurology 2001;56:323-327.

52. Walter MC, Lochmuller H, Toepfer M, et al. High-dose immunoglobulin therapy in sporadic inclusion body myositis: a doubleblind, placebo-controlled study. J Neurol 2000;247:22-28.

53. Albayda J, Mammen AL. Is statin-induced myositis part of the polymyositis disease spectrum? Curr Rheumatol Rep 2014;16: 433.

54. Mosca M, Strigini F, Carmignani A, D'Ascanio A, Genazzani AR, Bombardieri S. Pregnant patient with dermatomyositis successfully treated with intravenous immunoglobulin therapy. Arthritis Rheum 2005;53:119-121.

55. Ahmed AR, Gurcan HM. Use of intravenous immunoglobulin therapy during pregnancy in patients with pemphigus vulgaris. J Eur Acad Dermatol Venereol 2011;25:1073-1079. 
56. Miyasaka N, Hara M, Koike T, et al. Effects of intravenous immunoglobulin therapy in Japanese patients with polymyositis and dermatomyositis resistant to corticosteroids: a randomized doubleblind placebo-controlled trial. Mod Rheumatol 2012;22:382-393.

57. Danieli MG, Pettinari L, Moretti R, Logullo F, Gabrielli A. Subcutaneous immunoglobulin in polymyositis and dermatomyositis: a novel application. Autoimmun Rev 2011;10:144-149.

58. Gelardi C, Paolini L, Danieli MG. Subcutaneous immunoglobulin $\mathrm{G}$ in idiopathic inflammatory myopathies: therapeutic implications. Isr Med Assoc J 2014;16:646-647.

59. Marie I, Menard JF, Hachulla E, et al. Infectious complications in polymyositis and dermatomyositis: a series of 279 patients. Semin Arthritis Rheum 2011;41:48-60.

60. Frikha F, Rigolet A, Behin A, Fautrel B, Herson S, Benveniste O. Efficacy of rituximab in refractory and relapsing myositis with anti-JO1 antibodies: a report of two cases. Rheumatology 2009;48:1166-1168.

61. Lambotte O, Kotb R, Maigne G, Blanc F-X, Goujard C, Delfraissy JF. Efficacy of rituximab in refractory polymyositis. J Rheumatol 2005;32:1369-1370.

62. Majmudar S, Hall HA, Zimmermann B. Treatment of adult inflammatory myositis with rituximab: an emerging therapy for refractory patients. J Clin Rheumatol 2009;15:338-340.

63. Chiappetta N, Steier J, Gruber B. Rituximab in the treatment of refractory dermatomyositis. J Clin Rheumatol 2005;11:264-266.

64. Cooper MA, Willingham DL, Brown DE, French AR, Shih FF, White AJ. Rituximab for the treatment of juvenile dermatomyositis: a report of four pediatric patients. Arthritis Rheum 2007;56: 3107-3111.

65. Couderc M, Gottenberg J-E, Mariette X, et al. Efficacy and safety of rituximab in the treatment of refractory inflammatory myopathies in adults: results from the AIR registry. Rheumatology 2011;50:2283-2289.

66. Haroon M, Devlin J. Rituximab as a first-line agent for the treatment of dermatomyositis. Rheumatol Int 2012;32:1783-1784.

67. Feist E, Dorner T, Sorensen H, Burmester G-R. Longlasting remissions after treatment with rituximab for autoimmune myositis. J Rheumatol 2008;35:1230-1232.

68. Mok CC, Ho LY, To CH. Rituximab for refractory polymyositis: an open-label prospective study. J Rheumatol 2007;34:1864-1868.

69. Oddis CV, Reed AM, Aggarwal R, et al. Rituximab in the treatment of refractory adult and juvenile dermatomyositis and adult polymyositis: a randomized, placebo-phase trial. Arthritis Rheum 2013;65:314-324.

70. Munoz-Beamud F, Isenberg DA. Rituximab as an effective alternative therapy in refractory idiopathic inflammatory myopathies. Clin Exp Rheumatal 2013;31:896-903.

71. Whelan BR, Isenberg DA. Poor response of anti-SRP-positive idiopathic immune myositis to B-cell depletion. Rheumatology 2009;48:594-595.

72. Chung L, Genovese MC, Fiorentino DF. A pilot trial of rituximab in the treatment of patients with dermatomyositis. Arch Dermatol 2007;143:763-767.

73. Aggarwal R, Bandos A, Reed AM, et al. Predictors of clinical improvement in rituximab-treated refractory adult and juvenile dermatomyositis and adult polymyositis. Arthritis Rheumatol 2014;66:740-749.

74. Dalakas MC, Rakocevic G, Schmidt J, et al. Effect of Alemtuzumab (CAMPATH 1-H) in patients with inclusion-body myositis. Brain 2009;132:1536-1544.

75. Thompson B, Corris P, Miller JA, Cooper RG, Halsey JP, Isaacs JD. Alemtuzumab (Campath-1H) for treatment of refractory polymyositis. J Rheumatol 2008;35:2080-2082.

76. Kerola AM, Kauppi MJ. Abatacept as a successful therapy for myositis-a case-based review. Clin Rheumatol 2015;34:609-612.
77. Musuruana JL, Cavallasca JA. Abatacept for treatment of refractory polymyositis. Joint Bone Spine 2011;78:431-432.

78. Arabshahi B, Silverman RA, Jones OY, Rider LG. Abatacept and sodium thiosulfate for treatment of recalcitrant juvenile dermatomyositis complicated by ulceration and calcinosis. J Pediatr 2012;160:520-522.

79. Shimizu T, Tomita Y, Son K, Nishinarita S, Sawada S, Horie T. Elevation of serum soluble tumour necrosis factor receptors in patients with polymyositis and dermatomyositis. Clin Rheumatol 2000;19:352-359.

80. Anandacoomarasamy A, Howe G, Manolios N. Advanced refractory polymyositis responding to infliximab. Rheumatology 2005;44:562-563.

81. Dold S, Justiniano ME, Marquez J, Espinoza LR. Treatment of early and refractory dermatomyositis with infliximab: a report of two cases. Clin Rheumatol 2007;26:1186-1188.

82. Efthimiou P, Schwartzman S, Kagen LJ. Possible role for tumour necrosis factor inhibitors in the treatment of resistant dermatomyositis and polymyositis: a retrospective study of eight patients. Ann Rheum Dis 2006;65:1233-1236.

83. Hengstman GJD, van den Hoogen FHJ, Barrera P, et al. Successful treatment of dermatomyositis and polymyositis with anti-tumor-necrosis-factor-alpha: preliminary observations. Eur Neurol 2003;50:10-15.

84. Labioche I, Liozon E, Weschler B, Loustaud-Ratti V, Soria P, Vidal E. Refractory polymyositis responding to infliximab: extended follow-up. Rheumatology 2004;43:531-532.

85. Uthman I, El-Sayad J. Refractory polymyositis responding to infliximab. Rheumatology 2004;43:1198-1199.

86. Sprott H, Glatzel M, Michel BA. Treatment of myositis with etanercept (Enbrel), a recombinant human soluble fusion protein of TNF-alpha type II receptor and IgG1. Rheumatology 2004;43: 524-526.

87. Ishikawa Y, Yukawa N, Ohmura K, et al. Etanercept-induced antiJo-1-antibody-positive polymyositis in a patient with rheumatoid arthritis: a case report and review of the literature. Clin Rheumatol 2010;29:563-566.

88. Musial J, Undas A, Celinska-Lowenhoff M. Polymyositis associated with infliximab treatment for rheumatoid arthritis. Rheumatology 2003;42:1566-1568.

89. Urata Y, Wakai Y, Kowatari K, Nitobe T, Mizushima Y Polymyositis associated with infliximab treatment for rheumatoid arthritis. Mod Rheumatol 2006;16:410-411.

90. Klein R, Rosenbach M, Kim EJ, Kim B, Werth VP, Dunham J. Tumor necrosis factor inhibitor-associated dermatomyositis. Arch Dermatol 2010;146:780-784.

91. Hengstman GJD, De Bleecker JL, Feist E, et al. Open-label trial of anti-TNF-alpha in dermato- and polymyositis treated concomitantly with methotrexate. Eur Neurol 2008;59:159-163.

92. Dastmalchi M, Grundtman C, Alexanderson H, et al. A high incidence of disease flares in an open pilot study of infliximab in patients with refractory inflammatory myopathies. Ann Rheum Dis 2008;67:1670-1677.

93. Iannone F, Scioscia C, Falappone PC, Covelli M, Lapadula G. Use of etanercept in the treatment of dermatomyositis: a case series. J Rheumatol 2006;33:1802-1804.

94. Muscle Study Group. A randomized, pilot trial of etanercept in dermatomyositis. Ann Neurol 2011;70:427-436.

95. Lundberg I, Ulfgren AK, Nyberg P, Andersson U, Klareskog L. Cytokine production in muscle tissue of patients with idiopathic inflammatory myopathies. Arthritis Rheum 1997;40:865-874.

96. Dorph C, Dastmalchi M, Alexanderson H, et al. Anakinra treatment in patients with refractory inflammatory myopathies and possible predictive response biomarkers: a mechanistic study with 12 months follow-up. Ann Rheum Dis 2014;73:913-920. 
97. Lepidi H, Frances V, Figarella-Branger D, Bartoli C, MachadoBaeta A, Pellissier JF. Local expression of cytokines in idiopathic inflammatory myopathies. Neuropathol Appl Neurobiol 1998;24: 73-79.

98. Akira S, Hirano T, Taga T, Kishimoto T. Biology of multifunctional cytokines: IL 6 and related molecules (IL 1 and TNF). FASEB J 1990;4:2860-2867.

99. Narazaki M, Hagihara K, Shima Y, Ogata A, Kishimoto T, Tanaka T. Therapeutic effect of tocilizumab on two patients with polymyositis. Rheumatology 2011;50:1344-1346.

100. Murakami M, Nishimoto N. The value of blocking IL-6 outside of rheumatoid arthritis: current perspective. Curr Opin Rheumatol 2011;23:273-277.

101. Kaly L, Rosner I. Tocilizumab - a novel therapy for non-organspecific autoimmune diseases. Best Pract Res Clin Rheumatol 2012;26:157-165.

102. Okiyama N, Sugihara T, Iwakura Y, Yokozeki H, Miyasaka N, Kohsaka H. Therapeutic effects of interleukin-6 blockade in a murine model of polymyositis that does not require interleukin17A. Arthritis Rheum 2009;60:2505-2512.

103. Kazuki T, Bookbinder S, Furie R. A pilot study of eculizumab in patients with dermatomyositis. Arthritis Res 2002;46:S489.

104. Greenberg SA. Dermatomyositis and type 1 interferons. Curr Rheumatol Rep 2010;12:198-203.

105. Greenberg SA. Type 1 interferons and myositis. Arthritis Res Ther 2010;12(Suppl. 1):S4.

106. Higgs BW, Zhu W, Morehouse C, et al. A phase $1 \mathrm{~b}$ clinical trial evaluating sifalimumab, an anti-IFN-alpha monoclonal antibody, shows target neutralisation of a type I IFN signature in blood of dermatomyositis and polymyositis patients. Ann Rheum Dis 2014;73:256-262.

107. Fiechtner J, Montroy T. Treatment of moderately to severely active systemic lupus erythematosus with adrenocorticotropic hormone: a single-site, open-label trial. Lupus 2014;23:905-912.

108. Catania A, Gatti S, Colombo G, Lipton JM. Targeting melanocortin receptors as a novel strategy to control inflammation. Pharmacol Rev 2004;56:1-29.

109. Levine T. Treating refractory dermatomyositis or polymyositis with adrenocorticotropic hormone gel: a retrospective case series. Drug Des Devel Ther 2012;6:133-139.

110. Henes JC, Heinzelmann F, Wacker A, et al. Antisignal recognition particle-positive polymyositis successfully treated with myeloablative autologous stem cell transplantation. Ann Rheum Dis 2009; 68:447-448.

111. Holzer U, van Royen-Kerkhof A, van der Torre P, et al. Successful autologous stem cell transplantation in two patients with juvenile dermatomyositis. Scand J Rheumatol 2010;39:88-92.

112. Wang D, Zhang H, Cao M, et al. Efficacy of allogeneic mesenchymal stem cell transplantation in patients with drug-resistant polymyositis and dermatomyositis. Ann Rheum Dis 2011;70: 1285-1288.

113. Cherin P, Auperin I, Bussel A, Pourrat J, Herson S. Plasma exchange in polymyositis and dermatomyositis: a multicenter study of 57 cases. Clin Exp Rheumatol 1995;13:270-271.

114. Miller FW, Leitman SF, Cronin ME, et al. Controlled trial of plasma exchange and leukapheresis in polymyositis and dermatomyositis. N Engl J Med 1992;326:1380-1384.

115. Pons-Estel GJ, Salerni GE, Serrano RM, et al. Therapeutic plasma exchange for the management of refractory systemic autoimmune diseases: report of 31 cases and review of the literature. Autoimmun Rev 2011;10:679-684.

116. Azali P, Barbasso Helmers S, Kockum I, et al. Low serum levels of vitamin D in idiopathic inflammatory myopathies. Ann Rheum Dis 2013;72:512-516.

117. Ritterhouse LL, Crowe SR, Niewold TB, et al. Vitamin D deficiency is associated with an increased autoimmune response in healthy individuals and in patients with systemic lupus erythematosus. Ann Rheum Dis 2011;70:1569-1574.

118. Cutolo M. Further emergent evidence for the vitamin D endocrine system involvement in autoimmune rheumatic disease risk and prognosis. Ann Rheum Dis 2013;72:473-475.

119. Di Luigi L, Sottili M, Antinozzi C, et al. The vitamin D receptor agonist BXL-01-0029 as a potential new pharmacological tool for the treatment of inflammatory myopathies. PLoS One 2013;8: e77745.

120. Arnson Y, Amital H, Shoenfeld Y. Vitamin D and autoimmunity: new aetiological and therapeutic considerations. Ann Rheum Dis 2007;66:1137-1142.

121. Lundberg IE, Vencovsky J, Alexanderson H. Therapy of myositis: biological and physical. Curr Opin Rheumatol 2014;26:704-711.

122. Johnson LG, Collier KE, Edwards DJ, et al. Improvement in aerobic capacity after an exercise program in sporadic inclusion body myositis. J Clin Neuromuscul Dis 2009;10:178-184.

123. Kley RA, Tarnopolsky MA, Vorgerd M. Creatine for treating muscle disorders. Cochrane Database Syst Rev 2013;6:CD004760.

124. Hoogendijk JE, Amato AA, Lecky BR, et al. 119th ENMC international workshop: trial design in adult idiopathic inflammatory myopathies, with the exception of inclusion body myositis, 10-12 October 2003, Naarden, The Netherlands. Neuromuscul Disord 2004; 14:337-345.

125. Babu S, Li Y. Statin induced necrotizing autoimmune myopathy. J Neurol Sci 2015;351:13-17.

126. Grable-Esposito P, Katzberg HD, Greenberg SA, Srinivasan J, Katz J, Amato AA. Immune-mediated necrotizing myopathy associated with statins. Muscle Nerve 2010;41:185-190.

127. Mohassel P, Mammen AL. Statin-associated autoimmune myopathy and anti-HMGCR autoantibodies. Muscle Nerve 2013;48: 477-483.

128. Suzuki S, Nishikawa A, Kuwana M, et al. Inflammatory myopathy with anti-signal recognition particle antibodies: case series of 100 patients. Orphanet J Rare Dis 2015;10:61.

129. Valiyil R, Casciola-Rosen L, Hong G, Mammen A, ChristopherStine L. Rituximab therapy for myopathy associated with antisignal recognition particle antibodies: a case series. Arthritis Care Res 2010;62:1328-1334.

130. Barohn RJ, Amato AA, Sahenk Z, Kissel JT, Mendell JR. Inclusion body myositis: explanation for poor response to immunosuppressive therapy. Neurology 1995;45:1302-1304.

131. Zschuntzsch J, Voss J, Creus K, et al. Provision of an explanation for the inefficacy of immunotherapy in sporadic inclusion body myositis: quantitative assessment of inflammation and betaamyloid in the muscle. Arthritis Rheum 2012;64:4094-4103.

132. Lindberg C, Trysberg E, Tarkowski A, Oldfors A. Anti-Tlymphocyte globulin treatment in inclusion body myositis: a randomized pilot study. Neurology 2003;61:260-262.

133. Dobloug C, Walle-Hansen R, Gran JT, Molberg O. Long-term follow-up of sporadic inclusion body myositis treated with intravenous immunoglobulin: a retrospective study of 16 patients. Clin Exp Rheumatol 2012;30:838-842.

134. Muscle Study Group. Randomized pilot trial of betaINF1a (Avonex) in patients with inclusion body myositis. Neurology 2001;57:1566-1570

135. Muscle Study Group. Randomized pilot trial of high-dose betaINF-1a in patients with inclusion body myositis. Neurology 2004;63:718-720.

136. Barohn RJ, Herbelin L, Kissel JT, et al. Pilot trial of etanercept in the treatment of inclusion-body myositis. Neurology 2006;66: S123-S124.

137. Kosmidis ML, Alexopoulos H, Tzioufas AG, Dalakas MC. The effect of anakinra, an IL1 receptor antagonist, in patients with sporadic inclusion body myositis (sIBM): a small pilot study. J Neurol Sci 2013;334:123-125. 
138. Machado P, Miller A, Herbelin L, et al. Safety and tolerability of arimoclomol in patients with sporadic inclusion body myositis: a randomised, double-blind, placebo-controlled, phase IIa proof-ofconcept trial. Ann Rheum Dis 2013;72:A164.

139. Allenbach Y, Rigolet A, Guiguet M, et al. Efficacy of rituximab for the treatment of refractory inflammatory myopathies associated with anti-histidyl-tRNA synthetase antibodies (the FORCE Jo1 Study). Abstract Number 220, American College of Rheumatology Meeting, 2012

140. Coyle K, Pokrovnichka A, French K. A randomized double blind placebo controlled trial of infliximab in patients with polymyositis and dermatomyositis. Arthritis Res 2008;58:S293
141. Amato AA, Sivakumar K, Goyal N, et al. Treatment of sporadic inclusion body myositis with bimagrumab. Neurology 2014;83:18 .

142. Dorph C, Dastmalchi M, Alexanderson H, et al. Anakinra in patients with refractory idiopathic inflammatory myopathies. Arthritis Rheum 2009;60(Suppl.):589.

143. Barohn, RJ, Harbelin L, Kissel JT, King W, McVey AL, Saperstein DS. Pilot trial of etanercept in the treatment of sporadic inclusionbody myositis Neurology 2006;66(Suppl. 2):S123-S124.

144. Higgs BW, Zhu W, Morehouse C, et al. A phase $1 \mathrm{~b}$ clinical trial evaluating sifalimumab, an anti-IFN- $\alpha$ monoclonal antibody, shows target neutralisation of a type I IFN signature in blood of dermatomyositis and polymyositis patients. Ann Rheum Dis 2014;73:256-262. 